\title{
Graphics Visualization
}

National Cancer Institute

\section{Source}

National Cancer Institute. Graphics Visualization. NCI Thesaurus. Code C85439.

Computer methods for creating images, diagrams or animations. 